\title{
URGENSI PENDIDIKAN SEKS PADA ANAK USIA DINI
}

\author{
Alucyana \\ Universitas Islam Riau \\ E-mail: alucyana@fis.uir.ac.id \\ Raihana \\ Universitas Islam Riau \\ Email: raihana@fis.uir.ac.id \\ Orcid ld: 0000-0002-7078-5793, \\ Dian Tri Utami \\ Universitas Islam Riau \\ Email:diantriutami@fis.uir.ac.id
}

Article received: 14 November 2019, Review process: 09 Desember 2019

Article published: 30 Maret 2020

\begin{abstract}
We always assume that the world of children is a beautiful world, happy, safe and far from problems. Their time is always filled with fun and play. This statement is not entirely true, because behind a world filled with joy in children, real discomfort always lurks them. Negligence of parents who unwittingly make them trapped in unsafe conditions, for example, becoming victims of sexual abuse in early childhood. Not infrequently the perpetrators of sexual harassment are known people and people closest to them. Early childhood often becomes a victim because of verbal limitations and still lack of ability to express what is felt and experienced in detail and in detail. This condition is further strengthened by the lack of understanding of early childhood on the part of their body that can be touched and do not include what they should do when the unpleasant condition occurs. Therefore providing sex education to early childhood is important, so that the incidence of abuse in early childhood that can result in long-term trauma can be avoided. Sex education in early childhood is presented, of course, by following the age of their development and means of learning media that is suitable for early childhood. This sex education can be done by storytelling method, or playing pretend (pretendplay)
\end{abstract}

Keywords: sex education, early childhood, early childhood characteristics

\section{Abstrak}


Kita selalu menganggap bahwa dunia anak anak adalah dunia yang indah, bahagia, aman dan jauh dari masalah. Waktu mereka selalu di isi dengan keceriaan dan bermain. Pernyataan ini tentu tidak sepenuhnya benar, karena di balik dunia yang penuh dengan kegembiraan pada anak, ketidaknyamanan sesungguhnya selalu mengintai mereka. Kelalaian orangtua yang tanpa disadari membuat mereka terperangkap dalam kondisi tidak aman, contohnya menjadi korban pelecehan seksual pada anak usia dini. Tak jarang para pelaku pelecehan seksual tersebut adalah orang yang dikenal dan orang orang terdekat mereka. Anak usia dini kerap menjadi korban karena keterbatasan verbal dan masih kurangnya kemampuan untuk mengungkapkan apa yang dirasakan dan dialami secara detil dan terperinci. Kondisi ini semakin diperkuat dengan ketidakpahaman anak usia dini pada bagian tubuh mereka yang boleh disentuh dan tidak sertat indakan apa yang harus mereka lakukan saat kondisi idak menyenangkan itu terjadi. Oleh karena itu memberikan pendidikan seks pada anak usia dini menjadi penting, agar kejadian pelecehan pada anak usia dini yang dapat mengakibatkan trauma jangka panjang dapat dihindari. Pendidikan seks pada anak usia dini disajikan tentunya dengan mengikuti usia perkembangan mereka dan sarana media pembelajaran yang sesuai pada anak usia dini. Pendidikan seks ini dapat dilakukan dengan metode mendongeng, atau bermain pura pura (pretendplay)

Kata Kunci: Pretend Play, pendidikan seks, anak usia dini, karakteritik anak usia dini.

\section{PENDAHULUAN}

Pelecehan seksual terhadap anak merupakan masalah serius yang dapat merusak masa depan anak baik dalam jangka pendek dan jangka panjang bagi mereka yang menjadi korban (Berliner 2011, dalam Kerryann Walsh, Leisa Brandon, 2012). Konsekuensi lainnya pelecehan seksual yang terjadi juga berdampak pada keluarga, masyarakat dan ekonomi yang luas baik dalam hal kesehatan rehabilitasi, kesejahteraan, dan sistem peradilan biaya (Taylor et al. 2008 dalam Kerryann Walsh, Leisa Brandon 2012). Finkelhor (1979, dalam Christopher,B and Kathleen,K, 2004) dalam penelitiannnya menemukan 23\% anak perempuan yang berusia 7-9 tahun rentan menjadi korban perkosaan, sedangkan 32\% pada anak laki-laki usia 13-16 tahun. Dilaporkan juga bahwa $47 \%$ pelakunya adalah usia yang lebih tua dari mereka.

Pelecehan seksual dapat mengakibatkan sekelompok gejala psikologis khas pascatraumatis stres (Finkelhor 1979, Russell 1986, Johnson 1987, Kilgore 1988, Young 1992 dalam Murphy.J, 2001). Efek psikologis tersebut berakibat panjang pada korban perkosaan. 
Bahkan Runtz (dalam Christopher,B and Kathleen,K, 2004) menambahkan efek dari anakanak korban perkosaan adalah meningkatnya upaya bunuh diri dan merusak diri sendiri.

Melihat begitu banyaknya dampak psikologis pada anak korban perkosaan maka perlu diadakan penyembuhan. Dawson (1983, dalam Christopher, B and Kathleen, K, 2004) menyebutkan setidak nya ada 6 tujuan terapi untuk anak-anak yang menjadi korban kekerasan seksual diantaranya adalah mengajarkan seksualitas yang tepat. Tri Endang Jatmikowati, dkk (2015) menyebutkan bahwa Pendidikan seks untuk anak usia dini bukan mengajarkan anak melakukan seks bebas ketika mereka dewasa kelak. Pendidikan seks dimaksudkan agar anak memahami akan kondisi tubuhnya, tubuh lawan jenisnya, dan menghindarkan anak dari kekerasan seksual.

Nurul Chomaria (2014) menyebutkan pendidikan seks diawali dengan memperkenalkan bagian tubuh. Cara ini dapat digunakan melalui media gambar atau poster, lagu, dan permainan. Di Eropa seperti Inggis dan Irlandia mendukung bermain sebagai kerangka dasar kurikulum pada pendidikan anak usia dini (Whitebread, 2010). Salah satu permainan anak usia dini yang melegenda adalah permainan dengan pura-pura (pretend play). Istilah pretend play digunakan untuk jenis permainan saat anak-anak mulai mampu berkomunikasi secara transformatif dan secara kolektif mengubah objek, orang dan situasi dalam rangka menciptakan situasi non-literal atau 'seakan-akan'. Telah banyak penelitian dilaksanakan dalam rangka menyelidiki peran permainan pura-pura untuk Anak Usia Dini (Ahmad Mukhlis, 2016).

Penelitian ini dilaksanakan untuk menjawab permasalahan tentang: Bagaimanakah metode pretend play dalam mengajarkan pendidikan seks pada anak usia dini dan apakah penerapan metode pretend play dapat meningkatkan pengetahuan pendidikan seks pada anak usia dini?

Penelitian ini dilakukan bertujuan untuk 1) mendeskripsikan metode pretend play dalam mengajarkan pendidikan seks pada anak usia dini. 2) mengetahui peningkatan pemahaman pendidikan seks pada anak usia dini dengan menggunakan metode prentend play. 3) memberikan wawasan kepada orangtua dan para guru bagaimana mengajarkan pendidikan seks pada anak usia dini. 
Undang-undang tentang sistem pendidikan nasional menyatakan bahwa pendidikan anak usia dini adalah suatu upaya pembinaan yang ditujukan kepada anak sejak lahir sampai dengan usia enam tahun yang dilakukan melalui pemberian rangsangan pendidikan untuk membantu pertumbuhan dan perkembangan jasmani dan rohani agar anak memiliki kesiapan dalam memasuki pendidikan lebih lanjut (UU Nomor 20 Tahun 2003 Bab I Pasal 1 Ayat 14).

Menurut Yuliani Nurani, Sujiono (2009) Anak usia dini adalah anak yang baru dilahirkan sampai usia 6 tahun. Usia ini merupakan usia yang sangat menentukan dalam pembentukan karakter dan kepribadian anak . Sebagaimana yang dikemukakan oleh Plato seorang ahli filsafat (dalam Jamaris, 2005) bahwa waktu yang paling tepat mendidik anak adalah sebelum usia 6 tahun.

Lebih rinci Montessori (dalam Hainstock, 1999) mengungkapkan bahwa masa ini merupakan periode sensitif (sensitive periods), selama masa inilah anak secara khusus mudah menerima stimulus-stimulus dari lingkungannya. Pada masa ini anak siap melakukan berbagai kegiatan dalam rangka memahami dan menguasai lingkungannya karena pada masa ini juga anak mulai peka untuk menerima berbagai stimulasi dan berbagai upaya pendidikan dari lingkungan, baik disengaja maupun tidak disengaja. Hal ini terjadi karena adanya pematangan fungsi-fungsi fisik dan psikis sehingga anak siap merespon dan mewujudkan semua tugastugas perkembangan yang diterapkan muncul pada pola perilakunya sehari-hari

\section{Karakteritik Anak Usia Dini.}

Ada berbagai kajian tentang hakikat anak usia dini, khususnya anak TK diantaranya oleh Bredecamp, Coopple, Brener dan Kellough (dalam Masitoh dkk, 2005) sebagai berikut:

1. Anak bersifat unik artinya anak berbeda satu sama lain, anak memiliki bawaan, minat, kapabilitas, dan latar belakang kehidupan masing-masing.

2. Anak mengekspresikan perilakunya relatif spontan artinya perilaku yang ditampilkan anak umumnya relatif asli dan tidak ditutup-tutupi sehingga merefleksikan apa yang ada di dalam perasaan dan pikiran.

3. Anak bersifat aktif dan enerjik artinya anak lazimnya senang melakukan berbagai aktivitas, selama terjaga dari tidur, anak seolah-olah tak pernah lelah, tak pernah Bosan dan tak 
pernah berhenti dari beraktivitas, terlebih lagi kalau anak dihadapkan pada suatu kegiatan yang baru dan menantang.

4. Anak itu egosentris artinya anak lebih cenderung melihat dan memahami sesuatu dari sudut pandang dan kepentingannya sendiri.

5. Anak memiliki rasa ingin tahu yang kuat dan hantuasias terhadap banyak hal.

6. Anak bersifat eksploratif dan berjiwa petualang artinya terdorong oleh rasa ingin tahu yang kuat

7. Anak umumnya kaya dengan fantasi artinya anak senang dengan hal-hal yang imajinatif, dengan karakteristik ini, anak tidak saja senang terhadap cerita-cerita

khayal yang disampaikan oleh orang lain, tapi ia sendiri juga senang bercerita kepada orang lain.

8. Anak masih mudah frustasi artinya anak masih mudah kecewa bila menghadapi sesuatu yang tidak memuaskan.

\section{Prinsip-prinsip pembelajaran Anak Usia Dini}

1)Belajar melalui bermain, Anak di bawah usia 6 tahun berada pada masa bermain. Pemberian rangsangan pendidikan melalui bermain, dapat memberikan pembelajaran yang bermakna pada anak. 2) Berorientasi pada perkembangan anak, Pendidik harus mampu mengembangkan semua aspek perkembangan sesuai dengan tahapan usia anak. 3) Berorientasi pada kebutuhan anak pendidik harus mampu member rangsangan, pendidikan sesuai dengan kebutuhan anak, termasuk anak-anak kebutuhan khusus. 4) Berpusat pada anak, Pendidik harus menciptakan suasana yang mendorong semangat belajar, minat, kreativitas, inisiatif, dan kemandirian sesuai dengan karakteristik dan kebutuhan anak, 5) Pembelajaran aktif Pendidik harus mampu menciptakan suasana yang mendorong anak aktif mencari, menemukan, menentukan pilihan, mengemukakan pendapat, dan melakukan serta mengalami sendiri.

Dengan demikian, pengajaran yang dilakukan pada anak usia dini berbeda dengan pengajaran pada orang dewasa, seperti yang telah dijelaskan di atas. Untuk 
meningktkan seluruh potensi anak secara holistik maka berpedoman pada prinsip tersebut agar anak dapat tumbuh dan berkembang dengan baik.

\section{Pendidikan Seks Pada Anak Usia Dini}

\section{Pendidikan seksual}

Pendidikan seksual adalah upaya memberi pengetahuan yang benar kepada anak untuk menyiapkan anak beradaptasi secara baik dengan sikap-sikap seksual dimasa depan kehidupannya; dan pemberian pengetahuan ini menyebabkan anak memperoleh kecenderungan logis yang benar terhadap masalah-masalah seksual dan reproduksi Gawshi( Madani, 2003, dalam Aji dkk, 2018)).

Pendidikan seks memuat tiga cakupan yaitu penerangan atau penyuluhan (sex information), pengajaran (instruction), dan pendidikan (education in sexuality). Penyuluhan maksudnya memberikan penerangan duduk perkara dengan sebenarnya aktivitas seks yang disesuaikan dengan tingkat perkembangan dan golongan umur, di dalamnya memuat aspek biologis ( anatomi dan fisiologi) dari fungsi reproduksi. Sedangkan pendidikan seks memuat aspek etika, moral, agama, sosial, dan pengetahuan lain (Rosyid, 2007 dalam Aji,2018).

\section{Pendidikan seks pada anak usia dini}

Mengenalkan pendidikan seks sejak dini sangatlah penting, agar anak mampu membentengi dirinya dari kejahatan seksual. Nawita (2013) menjelaskan bahwa pendidikan seks adalah sebagai berikut : Pendidikan seks tidak lain adalah penyampaian informasi mengenai pengenalan (nama dan fungsi) anggota tubuh, pemahaman perbedaan jenis kelamin, penjabaran perilaku (hubungan dan keintiman) seks, serta pengetahuan tentang nilai dan norma yang ada di masyarakat berkaitan dengan gender.

Menurut Boyke D N dalam Madani Y(2003) Pendidikan sex pada anak-anak bukan mengajarkan cara-cara berhubungan sex semata, melainkan lebih kepada upaya memberikan pemahaman kepada anak sesuai dengan usianya, mengenai fungsi-fungsi alat sexsual dan masalah naluri alamiah yang mulai timbul: bimbingan mengenai pentingnya menjaga dan memelihara organ intim mereka, disamping juga memberikan pemahaman tentang perilaku pergaulan yang sehat serta resiko-resiko yang dapat terjadi seputar masalah seksual. Dengan 
demikian diharapkan anak-anak dapat lebih melindungi diri dan terhindar dari bahasa child seksual abuse.

Di sisi lain Gunarsa SD mengatakan, penyampaian materi pendidikan seksual ini seharusnya diberikan sejak dini ketika anak sudah mulai bertanya tentang perbedaan kelamin antara dirinya dan orang lain, berkesinambungan dan bertahap disesuaikan dengan kebutuhan dan umur anak serta daya tangkap anak (dalam psikologi praktis, anak, remaja dan keluarga, 1991). Dalam hal ini pendidikan sexsual idealnya diberikan pertama kali oleh orang tua di rumah, mengingat yang tahu keadaan anak adalah orang tuanya sendiri. Tetapi sayangnya di Indonesia tidak semua orang tua mau terbuka terhadap anak di dalam membicarakan masalah seksual, maka sebenarnya peran dunia pendidikan sangatlah besar (www.e-psikologi.com/an: 2002).

Berdasarkan beberapa definisi diatas, dapat disimpulkan bahwa pendidikan seks pada anak usia dini adalah upaya untuk pemberian informasi atau pengetahuan kepada anak usia dini mengenai mengidentifikasi anggota tubuh, bagian dan fungsi anggota tubuh, serta pentingnya menjaga anggota tubuh, serta perbedaan laki-laki dan perempuan.

\section{Metode Pretend Play}

Metode adalah cara yang digunakan untuk mengimplementasikan rencana yang sudah disusun dalam kegiatan nyata agar tujuan yang telah disusun tercapai secara optimal. (Wina Sanjaya, 2008). Sebagai konstruksi teoritis, tindakan berpura-pura (the act of pretence) didefinisikan sebagai non-literal, perilaku 'seakan-akan'. Berbagai budaya mengenal berbagai jenis permainan yang kemudian bermuara secara teoritis dalam jenis permainan berpura-pura (pretend play) seperti bermain simbolik (symbolic play), bermain peran (role-play), bermain imajinatif (imaginative play), bermain membuat-percaya (make-believe play), bermain fantasi (fantasy play), bermain dramatis (dramatic play) dan sosiodrama (sociodrama).

Garvey (1990) menyebut permainan berpura-pura mewajibkan pemainnya untuk memiliki daya atribusi dari setiap properti yang digunakan. Jarrold, Carruthers, Smith, dan Boucher (1994) menambahkan bahwa pretend play baik itu dilakukan secara individu maupun secara sosial belum tentu mewakili karakter yang diinginkan, namun kesemuanya 
tetap membutuhkan kemampuan representasional untuk membuat sebuah permainan dianggap sebagai 'pura-pura'.

Pretend play memiliki banyak nama. Beberapa di antaranya seperti permainan imajinasi, permainan kreatif, permainan fantasi (Karen. 2011). Pretend play adalah bentuk permainan yang mengandung unsur berpura-pura. Namun, permainan ini berbeda dengan bermain peran yang penekanannya pada peran yang dimainkan. Pretend play menekankan pada sejumlah peralatan yang menunjang permainan juga terdapat sejumlah peraturan. Vygotsky (dalam Rubin, 1983)

menyatakan, bahwa jenis permainan ini memungkinkan anak dapat memberikan arti terhadap objek dan perilaku, sehingga akan berkembang represansi simbol, yaitu anak dapat memberikan simbol terhadap apa yang dilihat dan dimainkan (Indrijati, dkk. 2016).

Menurut Dewi Retno Suminar (2008) Pretend play adalah bentuk permainan yang didalamnya mengandung unsur pura-pura. Permainan ini berbeda dengan role play, karena dalam pretend play selain terdapat sejumlah aturan juga menggunakan sejumlah peralatan dalam kegiatan bermain. Apabila role play penekanannya lebih pada peran yang dimainkan, maka dalam pretenpd play lebih pada peralatan yang dipakai juga menunjang unsur "purapura" dalam permainan. Kegiatan bermain pura-pura banyak dilakukan anak usia 3-7 tahun. Kegiatan anak dalam bermain pura-pura yaitu melakukan peran imajinatif memainkan peran tokoh yang dikenalnya melalui film ataupun dongeng (Mayke S. Tedjasaputra, 2005)

Heri Rahyubi (2012) menuturkan bahwa kelebihan metode pretend play adalah memupuk daya cipta, karena simulasi dilakukan dengan kreasi siswa masing-masing memainkan perannya, merangsang siswa untuk menjadi terampil dalam menanggapi suatu hal dan bertindak secara spontan, tanpa memerlukan persiapan dalam waktu lama dan memperkaya pengetahuan, sikap, dan ketrampilan serta pengalaman tidak langsung yang diperlukan dalam menghadapi berbagai situasi sosial yang problematik.

Dengan demikian dapat disimpulkan bahwa pretend play merupakan bentuk bermain aktif yang berhubungan dengan situasi sosial pada kehidupan nyata dan sering dilakukan oleh orang dewasa, namun mengandung unsur pura-pura misalnya: bermain rumah rumahan, sekolah sekolahan, belanja, dokter dan lain lain. 


\section{METODOLOGI}

Penelitian ini menggunakan jenis Penelitian Tindakan Kelas (PTK). Penelitian Tindakan Kelas adalah penelitian tindakan (Classroom Action Research) yang dilaksanakan dengan tujuan memperbaiki mutu praktik di kelasnya (Suharsimi, 2011). Prosedur Penelitian tindakan kelas memiliki prosedur yang terdiri dari tiga siklus, tiap tiap siklus dilaksanakan sesuai dengan perubahan yang ingin dicapai, yakni guna melihat Pendekatan Metode Pretend Play untuk Pendidikan Seks pada Anak Usia Dini TK IT Bunayya Pekanbaru (Studi Kasus Siswa PAUD). Penelitian proses pembelajaran di kelas yang terdiri dari 4 (empat) tahap, yaitu; (1) perencanaan tindakan, (2) pelaksanaan tindakan, (3) pengamatan, dan (4) refleksi. Tahapan siklus ini diharapkan dapat diperoleh data yang dikumpulkan sebagai jawaban dari permasalahan penelitian (Wahidmusni dan Nur Ali, 2008). Dalam melihat hasil pemahaman siswa PAUD tentang pelecehan seksual dengan menggunakan metode Pretend Play maka sebagai evaluasi awal dilakukan observasi partisipan. Observasi awal dilakukan untuk mengetahui tingkat pemahaman awal siswa PAUD tentang pelecehan seksual. Dalam observasi awal, refleksi dilakukan bahwa tindakan yang diterapkan adalah untuk meningkatkan pemahaman tentang pendidikan seks pada anak usia dini. PTK ini dilaksanakan melalui dua siklus untuk melihat pemahaman anak usia dini tentang pelecehan seksual melalui metode pretend play. Hasil analisis data dihitung secara kuantitatif dengan menggunakan persentase. Dalam menggunakan rumus persentase, dihitung dengan rumus persentase seperti dalam penilaian dengan persen yang banyak disebut percentages correction. Indikator keberhasilan tiap siklus adalah jika siswa dalam kelas telah mencapai nilai 100 ke atas sebanyak $100 \%$, maka dikatakan pembelajaran telah berhasil tuntas dan jika sebaliknya yaitu secara klasikal siswa yang mendapat nilai 100 ke atas kurang dari $100 \%$, maka dikatakan pembelajaran belum tuntas belajar.

\section{HASIL DAN PEMBAHASAN}

Berdasarkan hasil awal dan observasi pendidikan seks pada anak usia dini di TK IT Bunnayah diperoleh fakta bahwa pada proses pembelajaran yang sudah dilakukan oleh guru, belum pernah sebelumnya diajarkan tentang pendidikan seks untuk anak usia dini, hanya saja pembelajaran tentang anggota tubuh yang berkaitan dengan tema semester 1 di TK, yakni 
tema diriku sendiri, keluargaku, anggota tubuh sudah diajarkan. Hal-hal yang sudah diajarkan tidak diikutkan dengan pendidikan seks pada anak usai dini yang pada dasarnya merupakan materi-materi dalam pendidikan seks anak usia dini. Pada saat observasi ditemukan masalah diantaranya anak tidak mengetahui perbedaan anggota tubuh mana yang boleh dan tidak boleh dipegang oleh orang lain, perilaku baik dan bahaya, serta tidak mengetahui cara membentengi diri ketika bertemu orang asing. Setelah memperoleh fakta tersebut, peneliti merencanakan studi yang belum dilakukan sebelumnya dengan melalui metode pretend play diharapkan pemahaman anak tentang pendidikan seks dapat terwujud. Pembahasan tentang penelitian ini, yaitu tentang penggunaan metode pretend play untuk pendidikan seks anak usia dini di TK IT Bunayyah Pekanbaru. Untuk hasil data yang diperoleh setelah melakukan penelitian dapat dilihat pada uraian berikut ini:

Hasil penelitian ini memaparkan data kemampuan persentase klasikal anak memahami pendidikan seks anak usia dini melalui upaya metode pretend play untuk meningkatkan pemahaman siswa TK kelompok B di TK Bunayyah Pekanbaru. Data hasil pembelajaran awal akan didahulukan dipaparkan agar memudahkan penilaian memahami kemajuan anak.

\section{Data Siklus I, Upaya Peningkatan Pemahaman Pendidikan Seks pada Anak Usia Dini Melalui Metode Pretend Play Pada Siswa Kelompok B TK Bunayyah Pekanbaru.}

Selanjutnya hasil data pelaksanaan perbaikan pembelajaran yang dilaksanakan dengan menempuh langkah-langkah pembelajaran yang dimulai dari persiapan sarana pendukung, penilaian siklus dan melakukan tes unjuk kerja. Dari hasil penilaian tersebut diperoleh data hasil penilaian dengan perolehan nilai tiap-tiap siswa pada siklus I, untuk lebih jelas dapat dilihat pada penjelasan dibawah ini. Dari hasil penilaian yang dilakukan pada siklus I yakni diperoleh nilai tertinggi 91 dengan frekuensi 2 atau (12.5\%) dan nilai terendah adalah 49 dengan frekuensi 4 atau (25\%), dengan nilai rata-rata klasikal 50\%, siswa yang tuntas sebanyak 8 siswa (50\%), serta tidak tuntas sebanyak 8 siswa (50\%). Di bawah ini merupakan tabel distribusi data nilai berdasarkan hasil kemampuan siswa, untuk lebih jelas dapat dilihat pada tabel 3 . 
AWLADY: Jurnal Pendidikan Anak

Tabel 1: Distribusi Frekuensi Data Nilai Siklus I

\begin{tabular}{|l|l|l|l|}
\hline No & Interval & Frekuensi & Persentase \\
\hline 1 & $33-52$ & 5 & $31.25 \%$ \\
\hline 2 & $53-72$ & 3 & $18.75 \%$ \\
\hline 3 & $73-92$ & 8 & $50 \%$ \\
\hline & & 16 & $100 \%$ \\
\hline
\end{tabular}

Data Olahan Tahun 2019

Berdasarkan tabel di atas, dapat diperoleh data dengan interval penilaian siswa, yakni 5 siswa (31.25\%) dengan interval 33 - 52, 3 siswa (18.75\%) dengan interval 53 - 72, 8 siswa (50\%) dengan interval 73 - 92. Untuk lebih jelas dapat dilihat pada grafik 1.

\section{Grafik 1 : Hasil Tes Unjuk Kerja Siklus I}

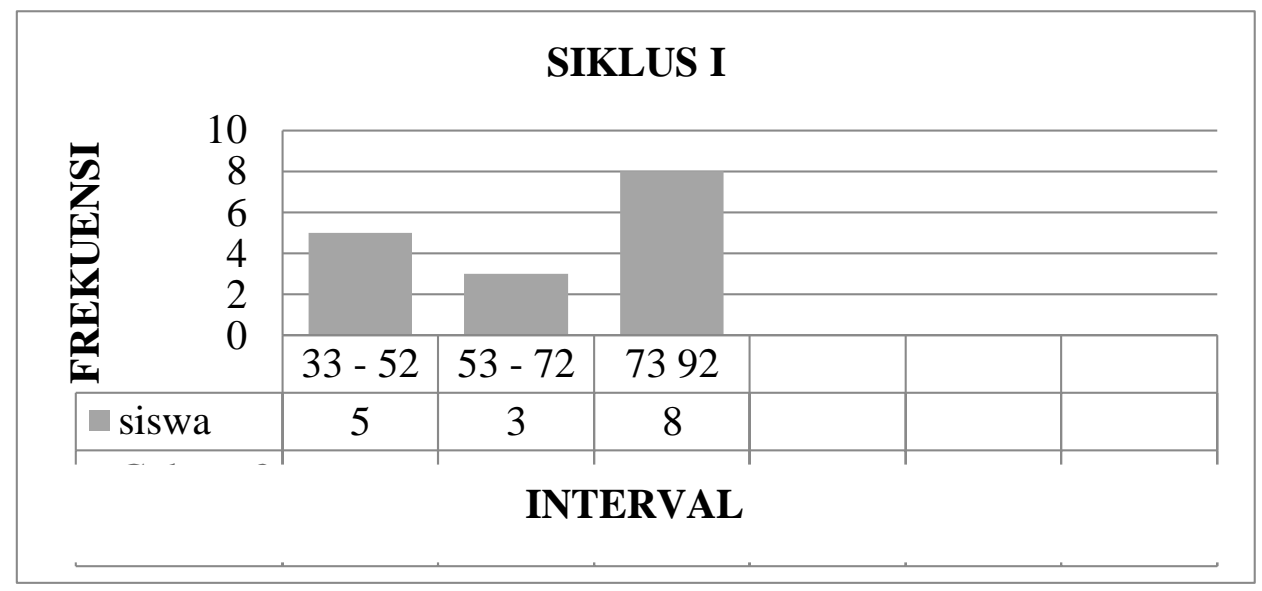

2. Data Siklus II Upaya Peningkatan Pemahaman Pendidikan Seks pada Anak Usia Dini Melalui Metode Pretend Play Pada Siswa Kelompok B TK Bunayya Pekanbaru.

Selanjutnya hasil data pelaksanaan perbaikan pembelajaran yang dilaksanakan dengan menempuh langkah-langkah pembelajaran yang dimulai dari persiapan sarana pendukung, dilakukan perencanaan siklus dan melakukan penilaian tes unjuk kerja. Dari hasil penilaian tersebut diperoleh data hasil penilaian dengan perolehan nilai tiap-tiap siswa pada siklus II, untuk lebih jelas dapat dilihat dari penjelasan di bawah ini. Dari hasil penilaian yang dilakukan pada siklus II yakni diperoleh nilai maksimal adalah 97 dengan frekuensi 2 atau (12.5\%) dan nilai minimal adalah 67 dengan frekuensi 1 (6.25\%), dengan rata-rata klasikal 
AWLADY: Jurnal Pendidikan Anak

Homepage: www.syekhnurjati.ac.id/jurnal/index.php/awlady

Email : pgrasyekhnurjati@gmail.com

P-ISSN: 2541-4658

E-ISSN: 2528-7427

93.75\% dan yang tuntas sebanyak 15 siswa (93.75\%), serta tidak tuntas sebanyak 1 siswa (6.25\%). Di bawah ini merupakan tabel distribusi data nilai berdasarkan hasil kemampuan siswa, untuk lebih jelas dapat dilihat pada tabel 2.

Tabel 2: Distribusi Frekuensi Data Hasil Siklus II

\begin{tabular}{|l|l|l|l|}
\hline No & Interval & Frekuensi & Persentase \\
\hline 1 & $33-47$ & 0 & 0 \\
\hline 2 & $48-62$ & 0 & 0 \\
\hline 3 & $63-77$ & 4 & $25 \%$ \\
\hline 4 & $78-92$ & 8 & $50 \%$ \\
\hline 5 & $93-107$ & 4 & $25 \%$ \\
\hline & & 16 & $100 \%$ \\
\hline
\end{tabular}

Olahan data tahun 2019

Berdasarkan tabel di atas, dapat diperoleh data dengan interval penilaian siswa yakni, 4 siswa (25\%) dengan interval $63-77,8$ siswa (50\%) dengan interval $78-92,4$ siswa (25\%) dengan interval 93 - 107. Untuk lebih jelas dapat dilihat pada grafik 2.

Grafik 2 : Hasil Tes Unjuk Kerja Siklus II.

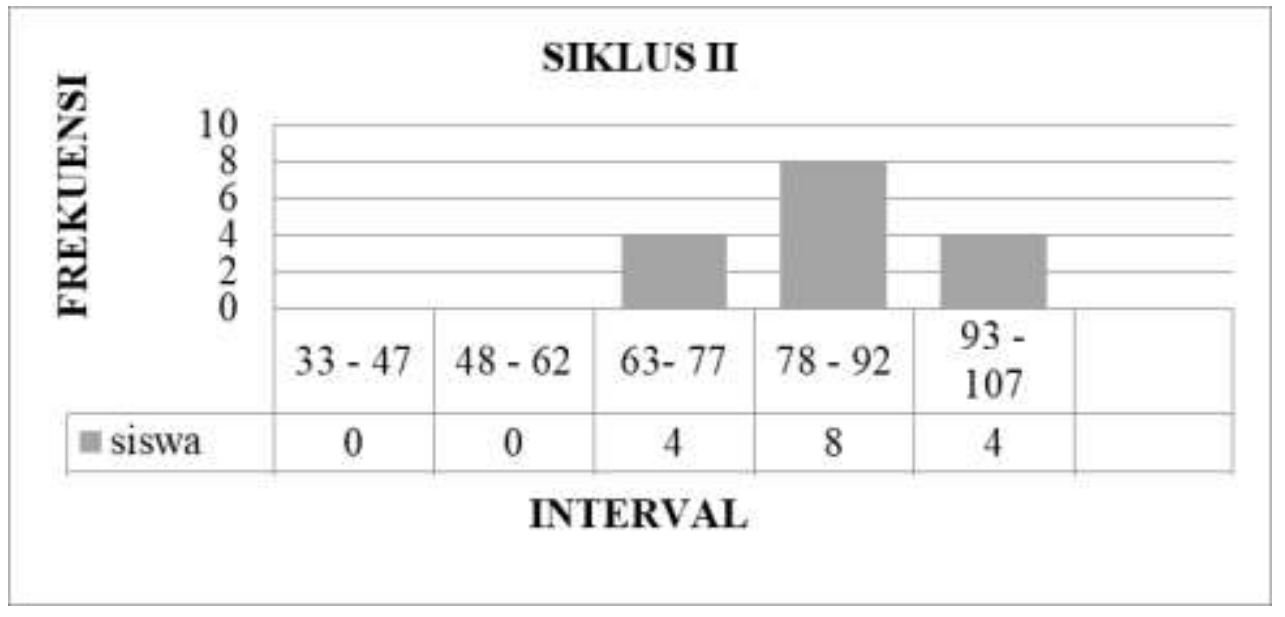

Berdasarkan data hasil pembelajaran, dimulai dari hasil data awal hingga melakukan perbaikan pembelajaran kesemua itu hasil pengamatan dan diskusi penulis dengan teman serta saran pihak-pihak yang ikut jalannya penelitian tindakan kelas ini, maka dapat dilihat bahwa 
dengan penerapan metode pretend play secara benar, maka aktivitas siswa menjadi lebih aktif dan meningkatkan pemahaman pendidikan seks pada anak usia dini lebih baik.

Untuk data siklus I menunjukan kategori tuntas terdapat 8 siswa atau (50\%), tidak tuntas sebanyak 8 siswa atau (50\%), sedangkan siklus II siswa yang tuntas sebanyak 15 siswa atau $(93.75 \%)$, dan tidak tuntas 1 siswa atau (6.25\%). Untuk lebih jelas mengenai peningkatan pemahaman pendidikan seks pada anak usia dini, dapat dilihat keterangan pembelajaran siswa dalam menggunakan metode pretend play dari data siklus I, dan siklus II pada tabel 5 di bawah ini:

Tabel 3: Perbandingan Pembelajaran

\begin{tabular}{|l|l|l|l|}
\hline Kategoori & Siklus I & Siklus II & Ket \\
\cline { 1 - 3 } Tuntas & $8(50 \%)$ & $15(93.75 \%)$ & $\begin{array}{c}\text { Adanya } \\
\text { peningkatan }\end{array}$ \\
\cline { 1 - 3 } Tidak Tuntas & $8(50 \%)$ & $1(6.25 \%)$ & \\
\cline { 1 - 3 } Jumlah & $16(100 \%)$ & $16(100 \%)$ & \\
\hline
\end{tabular}

Olahan data tahun 2019

Dari tabel di atas, dapat disimpulkan bahwa pada kegiatan siklus I siswa yang tuntas 8 orang, dan yang tidak tuntas 8 orang, dan siklus II siswa yang tuntas sebanyak 15 orang, dan tidak tuntas 1 orang, dengan metode pretend play terdapat peningkatan dan jenjang siswa dalam upaya meningkatkan pemahaman pendidikan seks pada anak usia dini dapat dilihat dari selisih peningkatan pembelajaran menggunakan metode pretend play pada grafik 3. 


\section{Grafik 3: Grafik Selisih Peningkatan.}

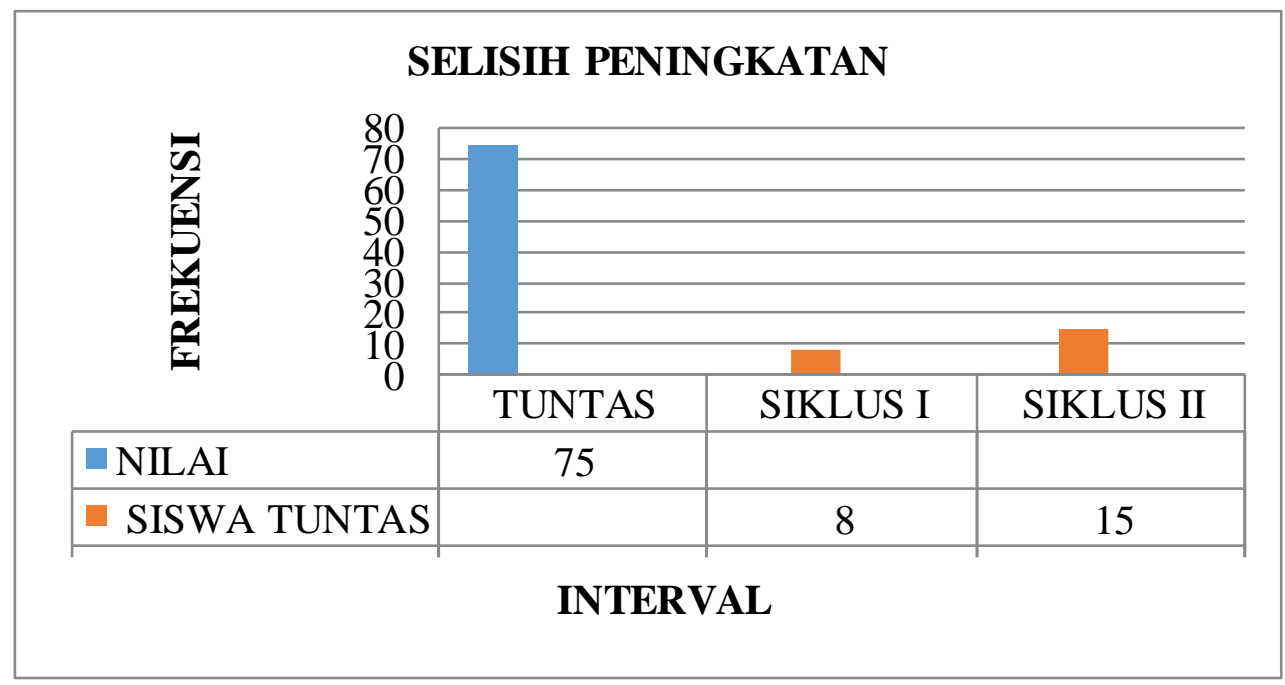

Dari grafik di atas, dapat diketahui bahwa indikator keberhasilan adalah 75, pencapaian siswa pada kegiatan siklus I sebesar 50\%, dan siklus II sebesar 93.75\% maka pada siklus 1 menuju siklus 2 terjadi peningkatan yang signifikan.

Berdasarkan dari data hasil penelitian, untuk mengetahui peningkatan pemahaman pendidikan seks pada anak usia dini menggunakan metode pretend play pada siswa Kelompok B di TK IT Bunayyah Pekanbaru. Dari hasil penilaian yang dilakukan pada siklus I yakni diperoleh nilai maksimum adalah 91 dan nilai minimum adalah 49, sedangkan siswa yang tuntas sebanyak 8 siswa atau (50\%), serta siswa yang tidak tuntas adalah 8 siswa atau (50\%). Sedangkan yang terdapat pada siklus II yakni diperoleh nilai maksimum adalah 97 sedangkan nilai minimum yang diperoleh adalah 67, serta siswa yang tuntas sebanyak 15 siswa atau (93.75\%), serta siswa yang tidak tuntas ada 1 siswa atau (6.25\%). Dari hasil pembelajaran siklus II masih ada indikator yang rendah yaitu siswa belum baik untuk menguasai perilaku, akan tetapi hasil pembelajaran telah mencapai 94\%. Untuk persentase secara keseluruhan pada siklus I 50\%, dan pada siklus II adalah 93\%.

Karena penelitian ini menggunakan metode pretend play banyak kendala yang ditemui dilapangan saat mengajar, metode pretend play prinsipnya belum akan diberikan bermain 
yang sesungguhnya sebelum unsur permainan itu dikuasai, maka dari itu banyak kendala yang ditemui saat dilapangan contohnya, siswa kesulitan dalam memerankan tokoh, dan siswa kurang memperhatikan guru saat menjelaskan pembelajaran, oleh karena itu disiklus I banyak siswa yang belum mencapai nilai indikator keberhasilan, maka dilanjutkan ke siklus II.

\section{SIMPULAN}

Penelitian Tindakan Kelas yang dilaksanakan di TK IT Bunayyah Pekanbaru menggunakan metode pretend play dalam hal pengenalan anak usia dini pada pendidikan seks. PTK ini telah dilaksanakan melalui dua siklus untuk melihat pemahaman anak usia dini tentang pelecehan seksual melalui metode pretend play. Adapun hasil yang didapat setelah pelaksanaan PTK adalah pada kegiatan siklus I siswa yang tuntas 8 orang, dan yang tidak tuntas 8 orang, dan siklus II siswa yang tuntas sebanyak 15 orang, dan tidak tuntas 1 orang, dengan metode pretend play terdapat peningkatan dan jenjang siswa dalam upaya meningkatkan pemahaman pendidikan seks pada anak usia dini dapat dilihat dari selisih peningkatan pembelajaran menggunakan metode pretend play. Ada beberapa kendala yang ditemui dilapangan saat mengajar,diantaranya yaitu metode pretend play prinsipnya belum akan diberikan bermain yang sesungguhnya sebelum unsur permainan itu dikuasai,

\section{DAFTAR PUSTAKA}

Abolghasemi N, Merghati Khoei E, Taghdissi H, (2013), Teachers' perceptions of sex education of primary school children, Mendeley, Volume 8, Issue 2.

AD Kusumaningtyas dan Ahmad Nurcholis, (2015), Seksualitas dan Agama: Kesehatan Reproduksi dalam Perspektif Agama-Agama, Jakarta: Gramedia.

Akhmad Mukhlis, (2016), Metakomunikasi anak usia dini: analisis dari permainan social berpura-pura, Pontianak, Book One Internasional Prooceeding Seminar "Pengembangan Potensi Anak Usia Dini"

Aji, Nhimas Ajeng Putri., Soesilo, Tritjahjo Danny., Windrawanto, Yustinus / Prosiding Seminar Nasional "Penguatan Pendidikan Karakter Pada Siswa Dalam Menghadapi Tantangan Global” Kudus, 11 April 2018

Arikuntho, Suharsimi dkk. (2011). Penelitian Tindakan Kelas. Jakarta: Bumi Aksara Bagley, Christoper \& King Katheleen, (2004). Child Sexual Abuse The Search for Healing, 29 West 35th Street, Inc 
Dewi Retno Suminar1,*, Th. Dicky Hastjarjo2, (2016), A Theoritical Model of Theory of Mind and Pretend Play, International Journal of Applied Psychology 2016, 6(4): 8593 DOI: 10.5923/j.ijap.20160604.02

Garvey, C. (1990). Play. Cambridge, MA: Harvard University Press.

Hakim, L, (2008), JURNAL EQUALITY, Vol. 13 No. 1 Februari 2008 Susanto, I. S. 1997. Kajian Kriminologis Kekerasan Terhadap Wanita, dalam Eko Prasetyo dan Suparman Marzuki, ed. Perempuan Dalam Wacana Perkosaan, Yogyakarta: Perkumpulan Keluarga Berencana Indonesia

Handayani, Alva dan Aam Amiruddin. (2008). Anak Anda Bertanya Seks? : Langkah Mudah Menjawab Pertanyaan Anak tentang Seks. Bandung: Khazanah.

Heri Rahyubi. (2012). Teori-teori Belajar dan Aplikasi Pembelajaran Motorik:

Deskripsi dan Tinjauan Kritis. Majalengka: Referens.

Jarrold, C., Carruthers, P., Smith, P.K., \& Boucher, J. (1994). Pretend play: Is it metarepresentational Mind and Language, 9(4), 445-467.

Karen Stagnitti. (2011). What is Pretend Play?. www.karenstagnitti.com

Kerryann Walsh, Leisa Brandon, (2012). Their Children's First Educators: Parents' Views About Child Sexual Abuse Prevention Education, Published online: 14 September 2011 Springer Science+Business Media, LLC 2011

Madani, Y. (2003). Pendidikan Seks Untuk Anak Dalam Islam. Jakarta: Pustaka Zahra.

Mayke S. Tedjasaputra. (2005). Bermain, Mainan dan Permainan. Jakarta:Grasindo.

Morris, R. (2006). Understanding child sexual abuse. 62nd Annual IARCCA ConferenceIndianapolis

Murphy.J. (2001).Art Therapy with Young Survivors of Sexual Abuse Lost forWords. Simultaneously published in the USA and Canada by Taylor \& Francis Inc.

Nawita, Muslik. (2013). Bunda, Seks itu Apa? : Bagaimana Menjelaskan Seks pada Anak. Bandung: Yrama Widya.

Nurhasmah, Wini. (2015). Implementasi Pendidikan Seksual untuk Anak Usia Dini. Skripsi. Bandung: Universitas Pendidikan Indonesia.

Nurul Chomaria, (2014), Pelecehan Anak, Kenali dan Tangani; Menjaga Buah Hati dari Sindrom. Cet. I: Solo: Tinta Medina.

Peraturan Menteri Pendidikan dan Kebudayaan nomor. 146 Tahun 2014 Tentang kurikulum 2013 Pendidikan Anak Usia Dini

Sari, A. P. (2009). Penyebab Kekerasan Seksual terhadap Anak dan Hubungan Pelaku dengan $\begin{array}{llllll}\text { Korban. } & \text { Diunduh tanggal } & 27 & \text { Juli } & 2009 & \text { dari }\end{array}$ http://kompas.com/index.php/read/xml/2009/01/28/

Sujiono, Yuliani Nurani. (2009). Konsep Dasar Pendidikan Anak Usia Dini. Jakarta: Indeks. 
Suminar, D.R. (1997). Pengaruh "Permainan Pura-Pura" Terhadap Perkembangan Bahasa Dan Kematangan Sosial AnakAnak Prasekolah. Thesis. Yogjakarta: Universitas Gadjah Mada

Supardi, S.\& Sadarjoen, “Dampak Psikologis Pelecehan Seksual pada Anak Perempuan”, http://www. kompas.com/kesehatan/news/0409/12/201621.htm, diakses 05 Desember 2006.

Susanto, I. S. (1997). Kajian Kriminologis Kekerasan Terhadap Wanita, dalam Eko Prasetyo dan Suparman Marzuki,ed.Perempuan Dalam Wacana Perkosaan, Yogyakarta: Perkumpulan Keluarga Berencana Indonesia

Tri Endang Jatmikowati, dkk, (2015), jurnal Cakrawala Pendidikan, Oktober 2015, Th. XXXIV, No. 3, Model danMateri Pendidikan Seks Anak Usia Dini Perspektif Gender untukMenghindarkan Sexual Abuse, FKIP Universitas Muhammadiyah Jember

Wahidmurni dan Nur Ali.( 2008). Penelitian Tindakan Kelas. Malang: UM PRESS.

Whitebread, D. (2010). Play, metacognition and self-regulation. In P. Broadhead, J. Howard, \& E. Wood (Eds.), Play and learning in the early years (pp. 161-176). London, UK: Sage.

Wina Sanjaya, (2008),Strategi Pembelajaran Berorientasi Standar Proses Pendidikan. Jakarta: Kencana Prenada Media Group. 